\title{
Economic evaluation of task-shifting approaches to the dispensing of anti-retroviral therapy
}

\author{
Nicola Foster ${ }^{*}$ and Diane McIntyre
}

\begin{abstract}
Background: A scarcity of human resources for health has been identified as one of the primary constraints to the scale-up of the provision of Anti-Retroviral Treatment (ART). In South Africa there is a particularly severe lack of pharmacists. The study aims to compare two task-shifting approaches to the dispensing of ART: Indirectly Supervised Pharmacist's Assistants (ISPA) and Nurse-based pharmaceutical care models against the standard of care which involves a pharmacist dispensing ART.

Methods: A cross-sectional mixed methods study design was used. Patient exit interviews, time and motion studies, expert interviews and staff costs were used to conduct a costing from the societal perspective. Six facilities were sampled in the Western Cape province of South Africa, and 230 patient interviews conducted.

Results: The ISPA model was found to be the least costly task-shifting pharmaceutical model. However, patients preferred receiving medication from the nurse. This related to a fear of stigma and being identified by virtue of receiving ART at the pharmacy.

Conclusions: While these models are not mutually exclusive, and a variety of pharmaceutical care models will be necessary for scale up, it is useful to consider the impact of implementing these models on the provider, patient access to treatment and difficulties in implementation.
\end{abstract}

Keywords: Task-shifting, Pharmaceutical care models, Skills mix, Anti-retroviral therapy

\section{Background}

The scarcity of human resources for health (HRH) has been identified as one of the primary constraints to the provision of anti-retroviral treatment (ART) to all who need it [1-3]. Pharmaceutical services experience similar workload pressures and staff shortages as those that plague other services involving HRH. While the World Health Organization's (WHO) guidelines recommend a minimum country average of 1 pharmacist per 2300 people, many low- and middle-income countries (LMIC) have averages far above that level. South Africa has 1 pharmacist per 4332 people [4]. In conjunction with international migration, and a preference for urban over rural posts, South Africa also experiences a strong pull of pharmacists away from the public health service and into the private sector, with approximately $24 \%$ of registered pharmacists employed in the public sector which

\footnotetext{
* Correspondence: Nicola.Foster@uct.ac.za

Health Economics Unit, School of Public Health and Family Medicine, University of Cape Town, Observatory, Cape Town, South Africa
}

serves more than $80 \%$ of the population [5]. This has led to a gap in the systems and processes associated with the safe provision of chronic (and specifically ART) drug treatment which is crucial as adherence is becoming of greater concern [4].

The substitution of scarce highly skilled health workers with purpose trained mid-level workers (termed task-shifting) is a logical strategy to address the scarcity of HRH [6]. The primary aim of task-shifting is to facilitate increased patient access to health services, through enabling a rapid scale-up of much needed health care interventions, and lower HRH training and salary costs [7]. In addition to the cost and efficiency benefits, midlevel workers have been found to be more likely to remain and work in rural areas and follow treatment guidelines. While quality of care has been cited as a concern by critics, studies suggest that the quality of care provided by mid-level workers is at least comparable to that of their more highly qualified colleagues [8-11]. A randomized non-inferiority trial conducted in primary
C Biomed Central 
health care clinics in South Africa (SA), which compared doctor- versus nurse-monitored ART care, found that nurse-monitored care was comparable to doctormonitored ART care and, therefore, supported taskshifting [11].

The shortage of pharmacists in the public health sector of SA has led to the use of pharmacists' assistants and nurses to support the expansion of the ART programme and to ensure that patients receive medication. However, evidence of the costs and benefits of these models is lacking. There is little consensus in the literature on the appropriate methodology to use in comparing HRH staff mix in a health system, although Fulton et al. (2011) have suggested that costeffectiveness analyses would be useful in ensuring that appropriate comparisons are made [7]. Thus far, the focus of staff mix evaluations has been on the delegation of tasks from doctors to physician assistants [9,12-18], from doctors to nurses [11,19-24], and from nurses to community health workers [25-30], with a paucity of studies referring to pharmaceutical care staff [31]. This study, therefore, aims to evaluate critically the indirectly supervised pharmacists' assistant (ISPA) and nurse-based pharmaceutical care models against the standard of care which involves a pharmacist dispensing ART, on the basis of cost, waiting and travel time and patient preference.

\section{Methods}

\section{Study design and setting}

A cross-sectional, mixed method study design was used. Data were collected using patient exit interviews, time and motion studies, and expert interviews. The study was conducted in a peri-urban district of the Western Cape province of SA.

\section{Sampling}

Within the district, health care facilities were grouped based on the pharmaceutical care model they used, with two facilities sampled per group. For each group an equal number of respondents was sampled, and the desired sample size per facility was proportional to the number of patients on treatment at the facility. Systematic sampling was used to select adult respondents on ART to interview while waiting for medication.

\section{Data collection}

A questionnaire was developed, piloted and intervieweradministered, to collect data regarding the direct and indirect costs incurred in accessing treatment as well as the acceptability of the service provided. Direct costs included the cost of transport, any facility fees incurred, the cost of employing someone to take over tasks (such as child minding), accommodation if sleeping over, and the cost of food and telecommunication while waiting at the facility. Indirect costs were estimated by asking respondents about income lost from taking time to come to the facility, as well as the cost of time spent travelling to the facility. Patient waiting time was estimated by attaching a printed form to each patient's folder, noting the time at which they entered the facility and pharmacy or nurse dispensers were asked to note the time at which respondents received their medicine. Collecting medication was considered to be the last contact point in the service chain. The difference in time was aggregated per facility and added to the average travel time to estimate the indirect cost per respondent per visit.

Health service expenditure and staffing data were obtained through facility observation and expert interviews with service managers. In order to determine the time spent by nurses on dispensing-related activities, the researcher observed practice and asked nurses to estimate time spent dispensing if a total of $100 \%$ represents one work day. The cost of HRH was estimated from Department of Health (DOH) advertisements for posts and discussed with service managers to ensure accuracy.

The potential cost of upgrading a medicine room to a dispensary, as required by the Pharmacy Act for a pharmacist's assistant to work in, was determined from a case study of a facility within the same district where the research was conducted, and sourced from the nongovernmental organization (NGO) which paid for the upgrade.

Respondent preferences were explored by asking whether they would prefer collecting medication from a local clinic or hospital, in addition to asking whether a nurse or pharmacist/pharmacist's assistant dispensing was preferable. Respondents were also asked to explain their preferences.

\section{Data analysis}

Statistical analysis of data was conducted using STATA $10^{\circledR}$ [32]. For examining health care costs, Microsoft Excel $^{\circledR}$ was used. All costs are presented in 2009/2010 prices and estimated costs were converted to US dollars at the average exchange rate of the US dollar to South African rand for the 2010 financial year of US $\$ 1=$ R7.80 [33].

The cost analysis was conducted from a societal perspective, and includes health service and patient costs. Given that the study is comparative, costs that are common across pharmaceutical care models were excluded [34]. For example, given that the cost of ARV drugs per patient does not vary between models, these costs were excluded [35]. The costs of staff employed by donors were included, in line with the donor mandate that these functions are to be taken over by the $\mathrm{DOH}$ in the future 
[36]. Although the inclusion of time costs is debated in the literature [37-39], patients' waiting and transport time, which differed significantly between facilities and could be seen as a measure of efficiency of service provision, were taken into account and the opportunity cost was calculated using the minimum hourly rate for a domestic worker in South Africa, US\$0.94 per hour [40]. While cost analysis assumes that outcomes are similar, an element of outcome measurement was included by considering the acceptability of the respective services. The open-ended or discussion questions of the exit interview responses were analyzed using domain analysis during which topics were identified, assigned a code, and domains and sub-categories explored. A list of codes was generated and used to explore the common (and different) perspectives of the respondents [41].

Preliminary results of the analysis were discussed with service managers to confirm assumptions and validate results.

\section{Ethics}

The research was approved by the University of Cape Town Health Science Faculty Human Research Ethics Committee as well as by the Western Cape Department of Health. The study was conducted in adherence to the Declaration of Helsinki of the $25^{\text {th }}$ World Medical Assembly and all respondents participated on the basis of written informed consent [42].

\section{Results}

Only 19 patients refused to be interviewed. Of the 230 patient exit interviews conducted, 6 were excluded from the analysis as respondents were either not on ART yet or were collecting medication for someone else.

\section{Respondent characteristics}

The characteristics of respondents are summarized in Table 1.

The unequal gender distribution of people who access ART in public health facilities has been well documented

\section{Table 1 Profile of respondents}

\begin{tabular}{llc}
\hline Characteristics & Number $(\boldsymbol{n}=\mathbf{2 2 4})$ & \% \\
\hline Gender & 62 & $27.7 \%$ \\
\hline male & 162 & $72.3 \%$ \\
\hline female & & \\
\hline Age & $36.2 \pm 9.2$ years & \\
\hline mean age \pm standard deviation & & \\
\hline Employment & 140 & $18.4 \%$ \\
\hline unemployed & 41 & $18.8 \%$ \\
\hline employed full-time & 42 & \\
\hline employed part-time & & \\
\hline
\end{tabular}

[43-45]. The age distribution of respondents, with a mean age of 36 years, is in line with the national profile of those on ART [46]. The unemployment rate is significantly higher at $62.8 \%$ than the overall Western Cape provincial estimate of $20.3 \%$ of the population [47]. This can partly be attributed to the organization of the SA health system whereby those employed are more likely to use private health care paid for by medical insurance.

\section{Facility characteristics}

The study was conducted in a peri-urban district, which includes some more rural facilities. Table 2 summarizes some of the key aspects of the service provided by the facilities sampled.

Pharm clinic 1 represents a relatively well resourced health centre, and had one full-time Pharmacist (Pharm), and a Pharmacist's Assistant (PA) exclusively dispensing ART, with two nurses using an estimated $60 \%$ of their working day in dispensing- related activities. This included taking prescriptions to the pharmacy to be filled, collecting medication and counseling patients on drug use. This arrangement came about after patients expressed their discomfort at waiting at the general pharmacy window to collect their medication. Pharm clinic 1 had the greatest proportion of Full-Time Equivalent (FTE) dispensing staff at 3.2 FTE compared to Pharm clinic 2 with 1.98 FTE. However, the ratio of patients on ART to FTE staff at Pharm clinic 1 was at 586:1 far greater than 419:1 at Pharm clinic 2 .

The ISPA facilities had similar absolute staff FTEs (1.2 versus 1.8) and ratios of patients on ART to FTE at 378:1 and 345:1, respectively. Thus, patient load does not explain the high average waiting time at ISPA clinic 1 of four hours and seventeen minutes (see Figure 1). This facility was struggling under the lack of a fulltime ART physician, which slowed down the renewal of prescriptions and ultimately the dispensing process. ISPA clinic 2 also had significant assistance in the dispensing process by the nurse; this included the ordering of medication for patients, and ensuring that the prescription is in order for patients only coming for repeat medication.

The nurse-driven group had the fewest FTE dispensers as nurses often only provided a once or twice weekly outreach service to the site. The time spent by the PA and Supervisory Pharmacist (SPharm) at the central pharmacy in preparing prescriptions in patient-ready packs was also included in the analysis. Notably the ratio of patients on ART to FTE dispenser was considerably lower than in either of the other pharmaceutical care models at 300:1 and 308:1, respectively. One can, therefore, argue that the number of patients per FTE dispensers required is highest for the pharmacist supported model, which may be due to the increased efficiency of "learning through doing" as these ART services have 
Table 2 Summary characteristics of ART service by facility

\begin{tabular}{|c|c|c|c|c|c|c|}
\hline & \multicolumn{2}{|c|}{ Group A: full-time pharmacist } & \multicolumn{2}{|c|}{$\begin{array}{l}\text { Group B: pharmacist assistant } \\
\text { under indirect supervision }\end{array}$} & \multicolumn{2}{|c|}{ Group C: nurse-driven } \\
\hline & Pharm clinic 1 & Pharm clinic 2 & ISPA clinic 1 & ISPA clinic 2 & Nurse clinic 1 & Nurse clinic 2 \\
\hline Level of service & $\mathrm{CDC}^{\mathrm{a}}$ & clinic & CDC & CDC & clinic & CDC \\
\hline $\begin{array}{l}\text { Pharmaceutical } \\
\text { care delivery } \\
\text { system }\end{array}$ & $\begin{array}{l}\text { A full-time pharmacist } \\
\text { and pharmacist's assistant } \\
\text { dispenses medication on } \\
\text { request, and sends the } \\
\text { patient-ready packs to } \\
\text { nurses to dispense to } \\
\text { patients. }\end{array}$ & $\begin{array}{c}\text { Full-time } \\
\text { pharmacist } \\
\text { dispenses directly } \\
\text { to patients, gives } \\
\text { adherence and } \\
\text { side-effects } \\
\text { counselling. }\end{array}$ & $\begin{array}{l}\text { PA working } \\
\text { under indirect } \\
\text { supervision } \\
\text { dispenses directly } \\
\text { to patients from } \\
\text { the general } \\
\text { pharmacy. }\end{array}$ & $\begin{array}{l}\text { PA working } \\
\text { under indirect } \\
\text { supervision } \\
\text { dispenses directly } \\
\text { to patients from } \\
\text { the general } \\
\text { pharmacy. }\end{array}$ & $\begin{array}{c}\text { Nurse does the } \\
\text { clinical examination } \\
\text { and dispenses ART } \\
\text { from patient-ready } \\
\text { packs ordered from } \\
\text { the central } \\
\text { pharmacy. }\end{array}$ & $\begin{array}{l}\text { Nurse does the } \\
\text { clinical examination } \\
\text { and dispenses ART } \\
\text { from patient-ready } \\
\text { packs ordered from } \\
\text { the central } \\
\text { pharmacy. }\end{array}$ \\
\hline \multirow{4}{*}{$\begin{array}{l}\text { Staff assisting in } \\
\text { pharmaceutical } \\
\text { care related }\end{array}$} & 1 Pharm & 0.66 Pharm & 0.2 sPharm $^{\mathrm{b}}$ & $0.2 \mathrm{SPharm}$ & $0.2 \mathrm{SPharm}$ & 0.2 SPharm \\
\hline & $1 \mathrm{PA}$ & $0.66 \mathrm{PA}$ & $1 \mathrm{PA}$ & $1 \mathrm{PA}$ & $0.2 \mathrm{PA}$ & $0.2 \mathrm{PA}$ \\
\hline & 0.6 Nurse & 0.66 PA & & 0.6 Nurse & 0.36 Nurse & 0.2 Nurse \\
\hline & 0.6 Nurse & & & & & 0.08 Nurse \\
\hline $\begin{array}{l}\text { Number of } \\
\text { patients on ART }\end{array}$ & 1874 & 829 & 454 & 621 & 228 & 210 \\
\hline $\begin{array}{l}\text { Ratio of FTE staff } \\
\text { to patients } \\
\text { enrolled in care }\end{array}$ & $1: 586$ & 1:419 & 1:378 & $1: 345$ & $1: 300$ & $1: 309$ \\
\hline $\begin{array}{l}\text { Average number } \\
\text { of months on } \\
\text { ART (SD) }\end{array}$ & 38 (12-52) months & $\begin{array}{c}28(15-49) \\
\text { months }\end{array}$ & 10 (4-21) months & 7 (4-15) months & 11 (5-15) months & 11 (6-23) months \\
\hline
\end{tabular}

ART, anti-retroviral treatment. FTE, full time equivalent; SD, standard deviation.

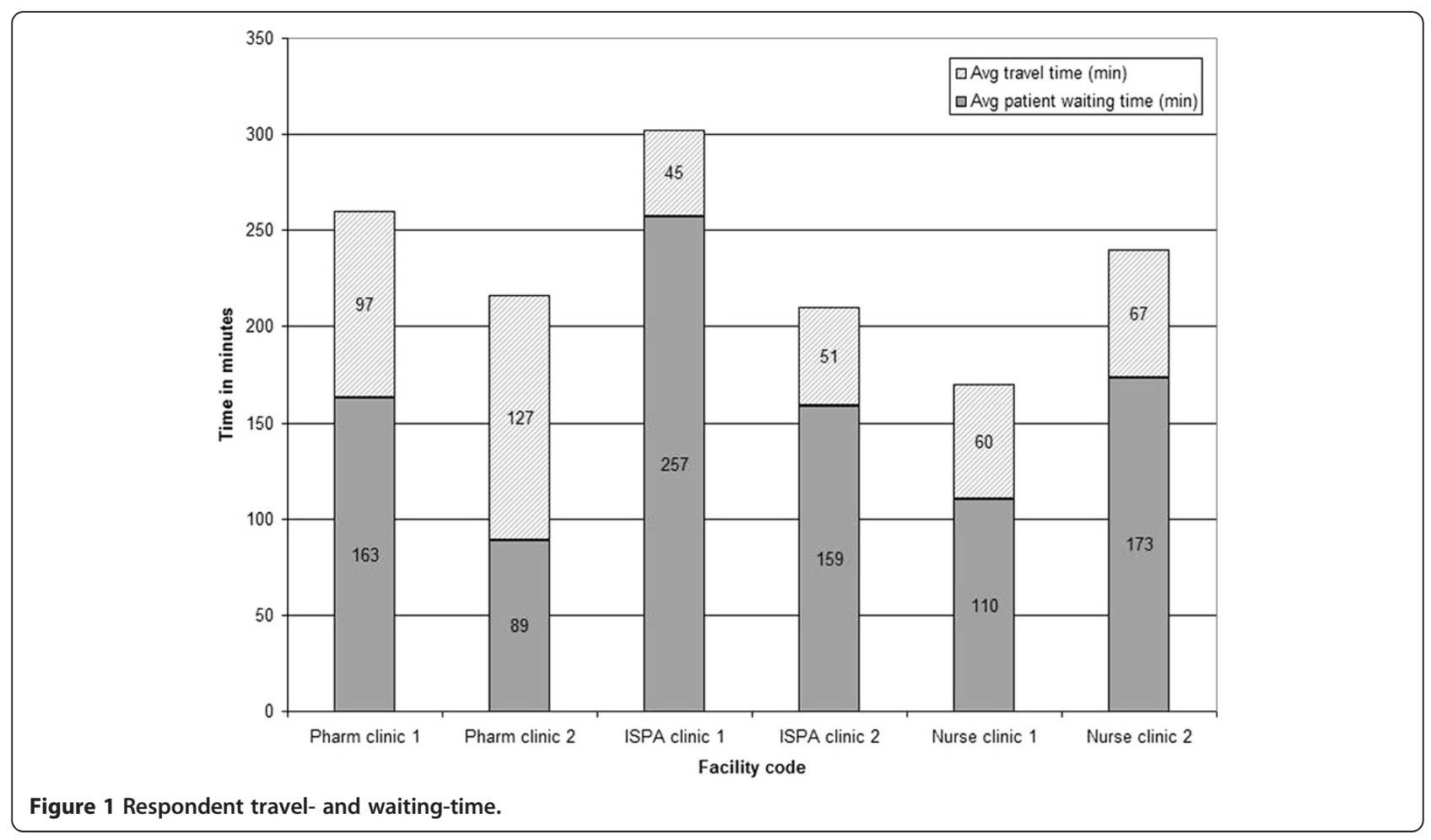


been operational for longer and serve more stable patients than the newer "outreach" nurse supported facilities. It is also conceivable that staff trained in dispensing (i.e., pharmacists and pharmacist's assistants) bring greater productive efficiency to the dispensing process and the service, therefore, takes longer to reach "saturation point" where new dispensing staff members are needed.

\section{Staff costs}

Given that the main difference between the pharmaceutical care models relates to the cost of $\mathrm{HRH}$, it was the primary focus in the cost analysis from the provider perspective. The provider (or staff) cost per patient visit (summarized in Table 3) for the nurse-driven pharmaceutical care model was at US\$10.16 almost double that of the pharmacist- or ISPA- models (US\$6.55 and US $\$ 5.74)$. This can be attributed largely to the difference in salaries between a pharmacist's assistant and a nurse.

In the ART programme, nurses working on outreach services are generally more experienced and compensated at a higher salary level. It is, therefore, important to consider the trade-off involved in shifting dispensing related tasks from pharmacists to nurses given the scarcity of nurses. One could argue that the nurse's time may be better spent performing clinical duties for which $\mathrm{s} /$ he is trained.

As would be expected, the direct costs incurred by patients accessing treatment, reflected the level of decentralization of the service. Patients paid the most at the pharmacist-led model facilities, where they spent almost four times more on transport than at the more decentralized ISPA- and nurse-driven facilities.

The cost of transport has been found to be a significant barrier to patient access to ART in other studies $[48,49]$. Similarly, when asked about the affordability of direct costs incurred in attending the clinic, $90 \%$ of the respondents at pharmacist-led and $67 \%$ at nurse-driven pharmaceutical care model facilities indicated that the costs incurred are unaffordable. This is certainly not surprising, given the high level of unemployment among respondents.

The average travel time is slightly less than that reported by other studies. Rosen et al. (2007) documented travel times (round trip) of between 83 and 158 minutes [50]. In this study, travel time was between 45 and 127 minutes per round trip (shown in Figure 1). However, it is interesting to note that respondents in Rosen's study were unlikely to walk to the facility while we found that up to $97 \%$ of patients from the more decentralized sites walked to the facility. This would also impact on the transport (direct) costs reported.

From the perspective of efficiency in service delivery, it is striking that the average waiting times are on average higher in the ISPA and nurse clinics (see Figure 1) although these facilities have relatively lower numbers of ART patients per FTE staff member (see Table 2).

The costs per patient visit are summarized by the pharmaceutical care modelin Table 4. The annual cost per patient was calculated by multiplying the cost to provider and patient per visit with the average number of visits per year reported in the patient exit interviews. There was less of a difference in the societal cost than in the provider cost between the ISPA and nurse pharmaceutical care models; this is because the high cost to the provider in the nurse model is partially offset by the relatively low cost to the patient due to the decentralized nature of the service.

While the annual cost per patient for the pharmacist model is lower than for the ISPA model, the average cost per visit is higher. This relates to the difference in the average number of patient visits per year. Patients who are stable and adherent on treatment are given enough medication for two months and would, therefore, on

Table 3 Average cost per patient visit $(n=244)$

\begin{tabular}{|c|c|c|c|c|c|c|}
\hline & \multicolumn{2}{|c|}{$\begin{array}{c}\text { Group A: } \\
\text { full-time pharmacist }\end{array}$} & \multicolumn{2}{|c|}{$\begin{array}{l}\text { Group B: pharmacist assistant } \\
\text { under indirect supervision }\end{array}$} & \multicolumn{2}{|c|}{$\begin{array}{c}\text { Group C: } \\
\text { nurse-driven }\end{array}$} \\
\hline & Pharm clinic 1 & Pharm clinic 2 & ISPA clinic 1 & ISPA clinic 2 & Nurse clinic 1 & Nurse clinic 2 \\
\hline \multicolumn{7}{|l|}{ Average provider cost } \\
\hline Staff costs & US\$6.08 & US\$7.01 & US\$5.09 & US\$6.38 & US\$11.19 & US\$9.13 \\
\hline Total cost to provider per patient visit & US\$6.08 & US\$7.01 & US\$5.09 & US\$6.38 & US\$11.19 & US\$9.13 \\
\hline \multicolumn{7}{|l|}{ Average patient costs } \\
\hline Direct costs & US\$6.20 & US\$3.35 & US\$1.59 & US\$1.65 & US\$1.14 & US\$3.00 \\
\hline Indirect costs ${ }^{a}$ & US\$5.42 & US\$5.09 & US\$7.47 & US\$4.15 & US\$3.60 & US\$4.84 \\
\hline Total cost to patient per visit & US\$11.62 & US\$8.45 & US\$9.06 & US\$5.81 & U\$4.74 & US\$7.84 \\
\hline Total societal costs for ART care per visit & US\$17.70 & US\$15.46 & US\$14.16 & US\$12.19 & US\$15.93 & US\$16.97 \\
\hline $\begin{array}{l}\text { Percentage of respondents who incurred } \\
\text { direct costs, and found it unaffordable (n) }\end{array}$ & $90 \%(36)$ & $70 \%$ (14) & $77.78 \%(21)$ & $68 \%(17)$ & $64.29 \%(9)$ & $70.97 \%(22)$ \\
\hline
\end{tabular}

${ }^{a}$ The average opportunity costs to those unemployed were estimated from the minimum daily rate for a domestic worker in South Africa (SA Department of Labor, 2010). 
Table 4 Incremental cost of ART service use, compared between different levels of service

\begin{tabular}{|c|c|c|c|c|c|}
\hline Level of service & $\begin{array}{l}\text { Average number } \\
\text { of patient } \\
\text { visits per year }\end{array}$ & Cost to provider & Cost to patient & Societal cost & $\begin{array}{l}\text { Average annual cost per } \\
\text { patient for baseline, incremental } \\
\text { cost for other models }\end{array}$ \\
\hline & & $\begin{array}{l}\text { Average cost } \\
\text { to provider per } \\
\text { visit for baseline, } \\
\text { incremental } \\
\text { cost for other } \\
\text { models }\end{array}$ & $\begin{array}{l}\text { Average cost } \\
\text { to patient per } \\
\text { visit for baseline, } \\
\text { incremental } \\
\text { cost for other } \\
\text { models }\end{array}$ & $\begin{array}{l}\text { Average cost } \\
\text { to society per } \\
\text { visit for baseline, } \\
\text { incremental } \\
\text { cost for other } \\
\text { models }\end{array}$ & \\
\hline $\begin{array}{l}\text { Full-time pharmacist } \\
\text { (baseline) }\end{array}$ & 7.78 & US\$ 6.55 & US\$ 10.04 & US\$16.58 & US\$128.99 \\
\hline ISPA & 10.74 & -US\$ 0.81 & -US\$ 2.60 & -US\$3.40 & US\$12.56 \\
\hline Nurse & 9.78 & US\$ 3.61 & -US\$ 3.75 & -US\$0.13 & US\$31.89 \\
\hline
\end{tabular}

average, only visit the facility six times per year. Given that the pharmacist model at more centralized facilities has been available for longer, their patients have been on treatment longer (see Table 2) and are, therefore, more likely to visit the clinic less often. This decreases the burden of care on the clinic and more patients can be seen using similar resources, while minimizing the cost to the patient.

The cost of upgrading a medicine room to a dispensary While the ISPA model is the cost saving option to the provider, there is an infrastructure upgrade required when moving from the nurse- to the ISPA-model. For the nurse model there is no need for a pharmacy or dispensary as medication is prepared for the patient at a central dispensary and merely handed out by the nurse in patient-ready packs. However, the ISPA model requires a dispensary to be registered with the South African Pharmacy Council. We present these costs separately and it is not included in the average cost comparison, as these medicine rooms should arguably be upgraded regardless of level of pharmaceutical care provided given that it is used for medication storage. It is however important to be aware of this potential additional cost. A case study from the district studied was selected and expenditure costs obtained to provide an idea of the approximate costs of an upgrade (Table 5).

A total cost of US\$11 479.88 was spent in the upgrading of the facility. The costs for the upgrade included enlarging of the medicine room, the installation of concrete beams in the room to improve security, installation of a security gate, shelving and the purchasing of a vaccine refrigerator as well as a backup household refrigerator.

\section{Sensitivity analysis}

A sensitivity analysis was conducted to test what the impact on the results would be if one were to vary some of the assumptions. While the baseline represents the current practice at the facilities, another "best practice" scenario was set up whereby the observed assistance of nursing staff in the pharmacist and ISPA models was disregarded and all patients visited the clinic every two months. The ratio of the cost for the ISPA to nurse models was similar for the baseline scenario (see Table 6). A "worst case" scenario was also set up, which involved nurses according to their estimates (at $90 \%$ of their productive time) and assumed that patients attended the clinic monthly. For scenario 2, the ISPA model was still less costly than the nurse model.

\section{Patient preferences}

The results of the cost analysis suggest that while both of the decentralized approaches, the ISPA- and nursedriven pharmaceutical care models, significantly decrease direct and indirect costs to patients when accessing treatment, the ISPA model once implemented would also be the least costly to the provider per patient visit (see Table 4). However, only considering the costs

Table 5 The cost of upgrading a medicine room to a dispensary

\begin{tabular}{lr}
\hline Description & $\begin{array}{r}\text { Cost (US } \\
\text { Dollars) }\end{array}$ \\
\hline $\begin{array}{l}\text { The modification and enlarging of medicine room to } \\
\text { dispensary }\end{array}$ & $\$ 2402.18$ \\
Security & $\$ 1089.74$ \\
Equipment & $\$ 1137.77$ \\
Shelving & $\$ 10.90$ \\
Signage & $\$ 5463.72$ \\
Electronic\& electrical & $\$ 166.35$ \\
Reference sources & $\$ 807.25$ \\
Dispensing & $\$ 401.97$ \\
General & $\$ 11479.88$ \\
Total &
\end{tabular}

Data sources: Lizette Monteith, Keth'Impilo; Lindsay Wilson, PGWC HIV directorate and Margaret von Zeil, City of Cape Town. 
Table 6 Sensitivity analyses of provider costs

\begin{tabular}{|c|c|c|c|c|c|}
\hline \multirow[t]{2}{*}{ Scenario } & \multirow[t]{2}{*}{ Models } & \multicolumn{2}{|l|}{ Assumptions } & \multirow{2}{*}{$\begin{array}{l}\text { Outcomes } \\
\begin{array}{l}\text { Average provider } \\
\text { cost/ visit }\end{array}\end{array}$} & \multirow[b]{2}{*}{$\begin{array}{l}\text { Annual provider cost } \\
\text { per patient }\end{array}$} \\
\hline & & Staff mix & $\begin{array}{l}\text { Number of patient } \\
\text { visits per year }\end{array}$ & & \\
\hline \multirow[t]{3}{*}{ Baseline } & $\begin{array}{l}\text { Full-time } \\
\text { pharmacist }\end{array}$ & & Based on exit interview & US\$6.55 & US\$50.95 \\
\hline & ISPA & & & US\$5.74 & US\$61.63 \\
\hline & Nurse-driven & & & US\$10.16 & US\$99.38 \\
\hline \multirow[t]{3}{*}{1} & $\begin{array}{l}\text { Full-time } \\
\text { pharmacist }\end{array}$ & One pharmacist and one pharmacists assistant & 6 & US\$4.61 & US\$27.64 \\
\hline & ISPA & $\begin{array}{l}\text { One supervisory pharmacist and one pharmacists } \\
\text { assistant }\end{array}$ & & US\$4.46 & US\$26.77 \\
\hline & Nurse-driven & One supervisory pharmacist and one nurse & & US\$11.11 & US\$66.65 \\
\hline \multirow[t]{3}{*}{2} & $\begin{array}{l}\text { Full-time } \\
\text { pharmacist }\end{array}$ & $\begin{array}{l}\text { One pharmacist, one pharmacist's assistant and } \\
\text { maximum nurse time estimate }\end{array}$ & 12 & US\$8.81 & US\$105.72 \\
\hline & ISPA & $\begin{array}{l}\text { Supervisory pharmacist, pharmacist's assistants and } \\
\text { maximum nurse time estimate }\end{array}$ & & US\$8.92 & US\$107.08 \\
\hline & Nurse-driven & $\begin{array}{l}\text { Supervisory pharmacist, pharmacist's assistants and } \\
\text { maximum nurse time estimate }\end{array}$ & & US\$18.80 & US\$225.62 \\
\hline
\end{tabular}

does not give us the full picture of the benefits or limitations of the specific models of care.

During the patient exit interviews, respondents were also questioned about whether they would prefer to receive their medication from the nurse or from the pharmacy. The response was most surprising from facilities where the ISPA model had already been implemented. The majority of respondents from these facilities indicated that they would prefer to receive their medication directly from the nurses. Here are some of their responses:

"I have to walk past people to get the pharmacy and they might recognise me. Also for the time saved" (Respondent, Pharm clinic 2)

"The people ask us so many questions that are not pleasant. I don't find it easy to collect them [her medication] at the pharmacy 'coz it is like automatic disclosure of my status to everyone" (Respondent, ISPA clinic 1)

Many of the responses reflected a spatial component to the stigma of HIV, related to being identified when seen by other community members collecting medication (visually known as ART) from the pharmacy. At one of the ISPA model facilities, the identification of people who are HIV positive was exacerbated by the use of a different colored folder for those who are not on ART.

The fear of stigma and the value of anonymity also played a central role in patients' choice of health facility. As some explained:

"I feel safer here; the people do not know me here. [It] would've been cheaper to go to [facility name] but [I] still rather come here." (Respondent, Pharm clinic 1)
"There are too many people in [facility name] and a lot of people there talk badly about HIV people."(Respondent, Pharm clinic 1)

"My child gets ARV's from [facility name] but I don't like it there. There are a lot of people there. If you go that side everyone knows you are positive. Here [current facility] we are not separate." (Respondent, Nurse clinic 1)

While respondents preferred receiving their medication directly from the nurse as opposed to the pharmacy as they felt that their anonymity was protected, there was a trade-off. A challenge of the nurse-driven pharmaceutical care model revolved around the logistics of ordering medication for each patient based on their latest prescription in advance of their appointment, and that patients sometimes arrived out of appointment dates, requesting medication. In an attempt to ensure that patient care continues, nurses would then open the pre-packed medication and dispense medication to patients from that source. This is how respondents described it:

"They give you "bietjie bietjie" [little, little] tablets with other people's names on. It confuses us." (Respondent, Nurse clinic 2)

"Last month I came and they gave me treatment for another person. Even now they gave me treatment for a week and it's not in my name." (Respondent, Nurse clinic 2)

"I don't like the fact that I would come on my date and leave the clinic without getting my pills, I have to 
take time away from work and my boss is not happy with it." (Respondent, Nurse clinic 2)

At one of the facilities, there were also concerns that medication ordered but not collected, was stored in a drawer. This left the stock open to be stolen, and if not stored under the correct conditions, it could compromise patient safety.

\section{Discussion}

Each of the pharmaceutical care models has a unique set of benefits and challenges, as summarized in Table 7 . The full-time pharmacist model is presented as the standard of care that would be the ideal at every facility and that has been found to promote rational prescribing and, therefore, been cost saving [51]. However, with the shortage of pharmacists, and an expensive four year training program, this approach would limit the scale-up of ART service provision.

The benefits of the ISPA model are that PAs undergo only a two year in-service training course supervised by a pharmacist. The PA dispenses directly to the patient and is responsible for stock control. In terms of supervision, one pharmacist can supervise up to five PAs simultaneously. Some concerns are that a PA might not be getting sufficient training, they have limited pharmacology training and do not have the authority to promote rational prescribing. Osman (2005) makes the point that PAs also lack a career path.

The nurse model is very useful in that it provides an option for the rapid scale-up of ART services, although it also reaches the saturation point sooner due to the difficulties of ordering medication for each patient appointment. Medication is not dispensed directly to patients but only from patient-ready packs with the help of standard operating procedures. While there is a perception that waiting time will be reduced when nurses dispense medication, it is more likely that consultation times will be longer and waiting times will increase.

Where there was a lack of doctors to renew prescriptions, this also resulted in increased waiting times and

Table 7 Comparison of Pharmaceutical Care models

\begin{tabular}{|c|c|c|c|}
\hline $\begin{array}{l}\text { Pharmaceutical } \\
\text { care provider }\end{array}$ & Full-time Pharmacist available & $\begin{array}{l}\text { Pharmacist's Assistant (PA) under } \\
\text { indirect supervision }\end{array}$ & Nurse-led service provision \\
\hline Overview & $\begin{array}{l}\text { Full-time pharmacist dispensing } \\
\text { medication from a prescription written } \\
\text { by a doctor, directly to the patient. }\end{array}$ & $\begin{array}{l}\text { The PA works under the indirect } \\
\text { supervision of an offsite pharmacist who } \\
\text { conducts monthly visits and provides } \\
\text { telephonic support. Dispenses directly to } \\
\text { patients from a legal prescription written } \\
\text { by a doctor. Responsible for stock control. } \\
\text { One pharmacist is allowed to supervise up } \\
\text { to fivePAs. }\end{array}$ & $\begin{array}{l}\text { This service is often provided in } \\
\text { conjunction with an outreach service from } \\
\text { a larger centre or in small satellite clinics. } \\
\text { Medication is pre-packed by a pharmacist } \\
\text { for each patient (patient-ready packs) and } \\
\text { delivered to the clinic from which the } \\
\text { nurse hands out the medication and } \\
\text { monitors the patients' condition. }\end{array}$ \\
\hline Requirements & $\begin{array}{l}\text { Service is available at larger facilities, for } \\
\text { example, at a community health centre. } \\
\text { Dispensing is conducted from a } \\
\text { pharmacy, operated under the personal } \\
\text { supervision of a responsible pharmacist, } \\
\text { licensed by the DOH and recorded with } \\
\text { SAPC. }\end{array}$ & $\begin{array}{l}\text { Dispensary has to be secure, organized, } \\
\text { temperature controlled. Pharmaceuticals } \\
\text { and related products are ordered, stored } \\
\text { and dispensed directly to clients by the PA } \\
\text { and issued to staff for treatment areas. } \\
\text { Dispensary design and layout is similar to } \\
\text { that of a pharmacy but with smaller floor } \\
\text { size. }\end{array}$ & $\begin{array}{l}\text { Storage of medication in a medicine room. } \\
\text { The medicine room is intended as a } \\
\text { secure, organized, temperature controlled } \\
\text { room with limited access, for the bulk } \\
\text { storage of pharmaceuticals, for refilling } \\
\text { trolleys or cupboards in treatment rooms. } \\
\text { No direct patient dispensing, only from } \\
\text { patient-ready packs or according to } \\
\text { standard operating procedures. }\end{array}$ \\
\hline \multirow[t]{3}{*}{ Benefits } & $\begin{array}{l}\text { Highly skilled and trained health } \\
\text { professional, experienced in working } \\
\text { under pressure and in a team. }\end{array}$ & $\begin{array}{l}\text { More cost-effective in salary and training } \\
\text { costs }[10]\end{array}$ & Increases access to ART for patient \\
\hline & $\begin{array}{l}\text { Promotes rational prescribing and is } \\
\text { therefore cost-saving }\end{array}$ & $\begin{array}{l}\text { Onsite to assist in stock management and } \\
\text { if patient comes outside of appointment } \\
\text { dates. }\end{array}$ & $\begin{array}{l}\text { Patients have established rapport with } \\
\text { clinician }\end{array}$ \\
\hline & & Increases access to ART & $\begin{array}{l}\text { There is a perception of time saved if } \\
\text { clinician dispenses, though each } \\
\text { consultation will take longer. }\end{array}$ \\
\hline \multirow[t]{4}{*}{ Problems } & Scarce & $\begin{array}{l}\text { Insufficient training (operational } \\
\text { management, dealing with the public/ } \\
\text { providers) }\end{array}$ & $\begin{array}{l}\text { Prescriber and dispenser is the same } \\
\text { person - potential for mistakes. }\end{array}$ \\
\hline & Would limit scale-up of ART service & $\begin{array}{l}\text { Does not have the authority/skill to } \\
\text { promote rational prescribing. }\end{array}$ & $\begin{array}{l}\text { Nurses might not be aware of drug } \\
\text { interactions between drug classes. }\end{array}$ \\
\hline & Expensive training & Limited pharmacology training & $\begin{array}{l}\text { Service is likely to reach saturation point } \\
\text { sooner. }\end{array}$ \\
\hline & Higher salary level & Lack of career path [52] & Higher salary level than PAs \\
\hline
\end{tabular}


more time spent by nurses being involved in the dispensing process. While nurse prescribing was not a model evaluated in this study, it has been proposed and might conceivably decrease waiting times. However, it does raise concerns when the prescriber and dispenser is the same person, as there is there is a lack of quality control.

The generalizability of this single district evaluation could be seen as a limiting factor given that the functioning of a facility is dependent on many facilityspecific characteristics, such as the level of skilled staff, skill mix, the infrastructure available and staff motivation [53]. However, the study does provide a framework within which to evaluate other facilities and some experiences will be common to many facilities. An additional limiting factor to the study is the lack of the facility staff members' opinions on issues such as the importance of the different color folders and influence on patients' access to treatment. Further research to explore health professionals' opinions is recommended.

\section{Conclusions}

In reality, these pharmaceutical care models are not mutually exclusive options and a variety of systems will no doubt be required to achieve scale-up. While the ISPA model is the least costly to the provider and to the patient, the concerns of patients in terms of confidentiality and the avoidance of stigma needs to be addressed as it could negatively impact on patients' health seeking behaviour. In contrast, the nurse-driven pharmaceutical care model is useful in rapidly scaling-up pharmaceutical care and indeed rolling-out ART service provision to new sites as capital outlay and the recruitment of dispensing personnel is not needed. It does however place a burden on nurses, uses more costly staff and reports suggest that pharmaceutical care may be compromised with patients needing to return to the health facility outside of scheduled appointments to collect medication due to them. Both of these pharmaceutical care models have a place in service provision, but it is imperative to address quality of care and confidentiality concerns of patients.

\section{Competing interests}

The authors declare that they have no conflicts of interest.

\section{Authors' contributions}

NF and DM conceptualized and designed the study. NF collected the data. NF and DM were involved in the analysis and drafted the manuscript. Both authors read and approved the final manuscript.

\section{Acknowledgements}

We would like to thank Ms Sibongile Bovana and Ms Vanessa Daries for their assistance and advice on fieldwork, A/Prof Susan Cleary for helpful comments on earlier drafts, and Ms Sheetal Silal for advice on the statistical aspects of the study. We also acknowledge the assistance of Dr Nelis Grobbelaar from Anova Health, and Dr Dirk Hagemeister in facilitating access to respondents. The study was made possible by the financial support of the
National Research Fund (NRF): Health and Wealth chair. The NRF had no further role in study design; in data collection, analysis and interpretation of data; in the writing of the report or in the decision to submit a paper for publication.

Received: 11 August 2011 Accepted: 13 June 2012 Published: 13 September 2012

\section{References}

1. Kober K, Van Damme W: Scaling up access to antiretroviral treatment in Southern Africa: who will do the job? Lancet 2004, 364:103-107.

2. Barnighausen T, Bloom DE, Humair S: Human resources for treating HIV/ AIDS: needs, capacities and gaps. AIDS Patient Care STDs 2007, 21:799-812.

3. Van Rensburg DH, Steyn F, Schneider H, Loffstadt L: Human resource development and antiretroviral treatment in Free State province, South Africa. Hum Resour Health 2008, 6:15-25.

4. King RC, Fomundam HN: Remodeling pharmaceutical care in Sub-Saharan Africa (SSA) amidst human resources challenges and the HIV/AIDS pandemic. Int J Health Plann Manage 2009, 25:30-48.

5. Pharmacy Human Resources Data. http://www.healthlink.org.za/healthstats/ 283/data. Accessed 17 July 2012.

6. Callaghan M, Ford N, Schneider $\mathrm{H}$ : A systematic review of task-shifting for HIV treatment and care in Africa. Hum Resour Health 2010, 8:8.

7. Fulton BD, Scheffer RM, Sparkes SP, Auh EY, Vujicic M, Soucat A: Health workforce skill mix and task shifting in low income countries: a review of recent evidence. Hum Resour Health 2011, 9:1-11.

8. Huicho L, Scherpbier RW, Nkowane AM, Victora CG: How much does quality of child care vary between health workers with differing durations of training? An observational multicountry study. Lancet 2008 372:910-916.

9. Kruk M, Pereira C, Vaz F, Bergstrom S, Galea S: Economic evaluation of surgically trained assistant medical officers in performing major obstetric surgery in Mozambique. Br J Obstet Gynaecol 2007, 114:1253-1260.

10. Dovlo D: Using mid-level cadres as substitutes for internationally mobile health professionals in Africa. A desk review. Hum Resour Health 2004, 2:7.

11. Sanne I, Orrell C, Fox M, Conradie F, Ive P, Zeinecker J, Cornell M, Heiberg C, Ingram C, Panchia R, Rassool M, Gonin R, Stevens W, Truter H, Dehlinger M, van der Horst C, McIntyre J, Wood R, CIPRA-SA Study Team: Nurse versus doctor management of HIV-infected patients receiving antiretroviral therapy (CIPRA-SA): a randomised non-inferiority trial. Lancet 2010, 376:33-40.

12. Chilopora G, Pereira C, Kamwendo F, Chimbiri A, Malunga E, Bergstrom S, Chilopora G, Pereira C, Kamwendo F, Chimbiri A, Malunga E, Bergstrom S: Postoperative outcome of ceasarean sections and other major emergency obstetric surgery by clinical officers and medical officers in Malawi. Hum Resour Health 2007, 5:17.

13. Herbertson R, Blundell A, Bowman C: The role of clinical support workers in reducing junior doctors' hours and improving quality of patient care. J Eval Clin Pract 2007, 13:272-275.

14. Pereira C, Bugalho A, Bergstrom S, Vaz F, Cotiro M: A comparative study of caesarean deliveries by assistant medical officers and obstetricians in Mozambique. Br J Obstet Gynaecol 1996, 103:508-512.

15. De Brouwere V, Dieng T, Diadhiou M, Witter S, Denerville E: Task shifting for emergency obstetric surgery in district hospitals in Senegal. Reprod Health Matters 2009, 17:32-44.

16. Hounton S, Newlands D, Meda N, De Brouwere V: A cost-effectiveness study of caesarean-section deliveries by clinical officers, general practitioners and obstetricians in Burkina Faso. Hum Resour Health 2009, 7:34.

17. McCord C, Mbaruku G, Pereira C, Nzabuhakwa C, Bergstrom S: The quality of emergency obstetrical surgery by assistant medical officers in Tanzanian district hospitals. Health Aff 2009, 28:w876-w855.

18. Brentlinger P, Assan A, Mudender F, Ghee A, Torres J, Martinez P, Bacon O, Bastos R, Manuel R, Li L, McKinney C, Nelson LJ: ask shifting in Mozambique: cross-sectional evaluation of non-physician clinicians' performance in HIV/AIDS care. Hum Resour Health 2010, 8:23.

19. Kinnersley P, Anderson E, Parry K, Clement J, Archard L, Turton P, Stainthorpe A, Fraser A, Butler C, Rogers C: Randomised controlled trial of nurse practitioner versus general practitioner care for patients requesting "same day" consultations in primary care. British Med J 2000, 320:1043-1048. 
20. Buchan J, Calman L: Skill-mix and policy change in the health workforce: Nurses in advanced roles. OECD Health Working Papers 17 2004, 8:63. http://www.oecd.org/dataoecd/30/28/33857785.pdf Accessed 20 July 2012.

21. Barber $S$, Gertler P, Harimurti P: The contribution of human resources for health to the quality of care in Indonesia. Health Aff 2007, 26:w367-w379.

22. Huicho L, Scherpbier R, Nkowane A, Victora C: The Multi-Country Evaluation of IMCI Study Group. How much does quality of child care vary between health workers with differing durations of training? An observational multicountry study. Lancet 2008, 372:910-916.

23. Shumbusho F, van Griensven J, Lowrance D, Turate I, Weaver M, Price J, Binagwaho A: Task shifting for scale-up of HIV care: evaluation of nurse-centered antiretroviral treatment at rural health centers in Rwanda. PLoS Med 2009, 6:e1000163.

24. Vasan A, Kenya-Mugisha N, Seung K, Achieng M, Banura P, Lule F, Beems M, Todd J, Madraa E: Agreement between physicians and non-physician clinicians in starting antiretroviral therapy in rural Uganda. Hum Resour Health 2009, 7:75.

25. Rowe S, Kelly J, Olewe M, Kleinbaum D, McGowan J, McFarland D, Rochat R, Deming M: Effect of multiple interventions on community health workers' adherence to clinical guidelines in Siaya district, Kenya. Trans $R$ Soc Trop Med Hyg 2007, 101:188-202.

26. Rahman A, Malik A, Sikander S, Roberts C, Creed F: Cognitive behaviour therapy-based intervention by community health workers for mothers with depression and their infants in rural Pakistan: a cluster-randomised controlled trial. Lancet 2008, 372:902-909.

27. Gary T, Batts-Turner M, Yeh H, Hill-Briggs F, Bone L, Wang N, Levine D, Powe N, Saudek C, Hill MN, McGuire M, Brancati FL: The effects of a nurse case manager and a community health worker team on diabetic control, emergency department visits, and hospitalizations among urban African Americans with type 2 diabetes mellitus: a randomized controlled trial. Arch Intern Med 2009, 169:1788-1794.

28. Wools-Kaloustian K, Sidle J, Selke H, Vedanthan R, Kemboi E, Boit L, Jebet V, Carroll A, Tierney W, Kimaiyo S: A model for extending antiretroviral care beyond the rural health centre. J Int, AIDS SOC 2009, 12:22.

29. Lewin S, Munabi-Babigumira S, Glenton C, Daniels K, Bosch-Capblanch X, van Wyk B, Odgaard-Jensen J, Johansen M, Aja G, Zwarenstein M, Scheel I: Lay health workers in primary and community health care for maternal and child health and the management of infectious diseases. Cochrane Database Syst Rev 2010, 3:CD004015.

30. Selke H, Kimaiyo S, Sidle J, Vedanthan R, Tierney W, Shen C, Denski C, Katschke A, Wools-Kaloustian K: Task-shifting of antiretroviral delivery from health care workers to persons living with HIV/AIDS: clinical outcomes of a community-based program in Kenya. J Acquir Immune Defic Syndr 2010, 55:483-490

31. Monteith L, Grimwood A, Pillay K: Improve access of ART at the PHC level through indirectly supervised pharmacist assistants. Cape Town: Keth'Impilo; 2010.

32. StataCorp: Stata Statistical Software. 10th edition. College Station, Texas: StataCorp LP; 2007

33. Average Yearly Exchange Rates. www.oanda.com.

34. Drummond M, Sculpher M, Torrance G, O'Brien B, Stoddart G: Methods for the Economic Evaluation of Health Care Programmes. 3rd edition. United Kingdom: Oxford University Press; 2005.

35. Johns B, Baltussen R, Hutubessy R: Programme costs in the economic evaluation of health interventions. Cost Eff Resour Alloc 2003, 1:1

36. Creese A, Parker D: Cost Analysis in Primary Health Care: A Training Manual forProgramme Managers. Geneva: World Health Organization; 1994.

37. Garrison LP, Mansley EC, Abbott I, Bresnahan BW, Hay JW, Smeeding J: Good research practices for measuring drug costs in cost-effectiveness analyses: asocietal perspective. Value Health 2010, 13:8-13.

38. Meltzer D, Johannesson M: Inconsistencies in the "societal perspective" on costs of the panel on cost-effectiveness in health and medicine. Med Decision Making 1999, 19:371-377.

39. Drummond M, Sculpher M, Torrance G, O'Brien B, Stoddart G: Methods for the Economic Evaluation of Health Care Programmes. 3rd edition. Oxford: Oxford University Press; 2005

40. What Domestic Workers and Their Employers Should Know about Minimum Wages and Conditions of Employment. Accessed 17 July 2012. https://www. labour.gov.za/documents/useful-documents/basic-conditions-ofemployment/what-domestic-workers-and-their-employers-should-knowabout-minimum-wages-and-conditions-of-employment.
41. Atkinson S, El haj MA: Domain analysis for qualitative public health data. Health Policy Plan 1996, 11:438-442.

42. Declaration of Helsinki. 2008

43. Schneider H, Mclntyre D, Birch S, Eyles J: Access challenges in TB, ART and maternal health services. REACH: Phase 1 results; 2009. http://uct-heu.s3. amazonaws.com/wp-content/uploads/2010/02/USER-REPORT.pdf. Accessed 17 July 2012.

44. Ingle S, May M, Uebel K, Timmerman V, Kotze E, Bachman M, Sterne J, Egger M, Fairall L: Differences in access and patient outcomes across antiretroviral treatment clinics in the Free State province: a prospective cohort study. S Afr Med J 2010, 100:675-681.

45. Muula A, Ngulube T, Siziya S, Makupe C, Umar E, Prozesky H, Wiysonge C, Mataya R: Gender distribution of adult patients on highly active antiretroviral therapy (HAART) in Southern Africa: a systematic review. Public Health 2007, 7:63-71.

46. Cornell M, Technau K, Fairall L, Wood R, Moultrie H, van Cutsem G, Giddy J, Mohapi L, Eley B, MacPhail P, Prozesky H, Rabie H, Davies MA, Maxwell N, Boulle A, International Epidemiologic Databases to Evaluate AIDS SouthernAfricaCollaboration: Monitoring the South African National Antiretroviral Treatment Programme, 2003-2007: The leDEA Southern Africa collaboration. S Afr Med J 2009, 99:653-660.

47. Statistics South Africa: Quarterly labour force survey. Statistics South Africa; 2011:P0211. http://www.statssa.gov.za/publications/P0211/ P02111stQuarter2011.pdf Accessed 20 July 2012.

48. Fredlund VG, Nash J: How far should they walk? Increasing antiretroviral therapy access in a rural community in Northern KwaZulu-Natal, South Africa. J Infect Dis 2007, 196:S469-S473.

49. Tuller DM, Bangsberg DR, Senkungu J, Ware NC, Emenyonu N, Weiser SD: Transportation costs impede sustained adherence and access to HAART in a clinic population in southwestern Uganda: aqualitative study. AIDS Behav 2010, 14:778-784.

50. Rosen S, Ketlhapile M, Sanne I, DeSilva MB: Cost to patients of obtaining treatment for HIV/Aids in South Africa. S Afr Med J 2007, 97:524-529.

51. Munroe W, Kunz K: Economic evaluation of pharmacist involvement in disease management in a community pharmacy setting. Clin Ther 1997, 19:113-123.

52. Osman $L$ : The challenge of indirect supervision. S Afr Pharmacist Assist 2005, 4.

53. Evans D: Hierarchy of evidence: a framework for ranking evidence evaluating healthcare interventions. J Clin Nurs 2003, 12:77-84.

doi:10.1186/1478-4491-10-32

Cite this article as: Foster and McIntyre: Economic evaluation of task-shifting approaches to the dispensing of anti-retroviral therapy. Human Resources for Health 2012 10:32.

\section{Submit your next manuscript to BioMed Central and take full advantage of:}

- Convenient online submission

- Thorough peer review

- No space constraints or color figure charges

- Immediate publication on acceptance

- Inclusion in PubMed, CAS, Scopus and Google Scholar

- Research which is freely available for redistribution 